\title{
THE DURABLE DEVELOPMENT OF THE FRUIT FARMING SEGTOR IN ROMANIA
}

\section{Cristina Gabriela DUMITRU ${ }^{\mathrm{a}, *}$, Bogdan Cristian CHIRIPUCI ${ }^{\mathrm{b}}$ \\ a),b) Bucharest University of Economic Studies, Faculty of Agro-Food and Environmental Economics, Bucharest, Romania}

Please cite this article as:

Article History:

Dumitru, C.G. and Chiripuci, B.C., 2017. The durable development of the fruit farming sector in Romania. Review of Economic Studies and Research Virgil Madgearu, 10(1), pp.69-75.

doi: 10.24193/RVM.2017.10.05.

Abstract: Upon acknowledging the environmental problems, a concept of durable development has emerged. Initially formulated and presented during the environmental Conference in 1972 in Stockholm, durable developmet so becomes recognized at a global level. Durable development brings together environmental objectives as well as socio-economical objectives. Furthermore, it represents a fundamental objective of the European Union. With Romania aderation to the European Union, our country has to align itself to all the standards of the community it joined, so, the concept of durable development has been more and more frequently met and taken into account during economical, social and environmental activities taken place all around the country.

Key words: durable development; fruit growing JEL Classification: $\mathrm{O}_{3}$; $Q O$

(C) 2017 Alma Mater Publishing House. All rights reserved.

* Corresponding author. E-mail address: cg.dumitru@yahoo.com. 


\section{References}

1. Guvernul României, 2008. Strategia Naţională pentru Dezvoltare Durabilă a României. Orizonturi 2013-2020-203O. [online] Avalilable at: www.mmediu.ro.

2. Sub-programul pomicol. [online] Avalilable at: www.madr.ro.

3. Institutul Naţional de Statistică. Avalilable at: www.insse.ro.

4. PNDR 2020. [online] Avalilable at: www.pndr2020.ro.

5. Rădulescu, C.V., 2003. Dezvoltarea durabilă şi implicaţiile economico-financiare ale organizării exploataţiilor agricole. București: Editura ASE. 